\title{
PLAN
}

PROFESSORAS: DIMENS PSÍQUICAS, HISTÓRI E EDUCAT 


\section{PLANTAS PROFESSORAS: DIMENSÕES PSÍQUICAS, HISTÓRICAS E EDUCATIVAS}




\section{PLANTAS PROFESSORAS: DIMENSÕES PSÍQUICAS, HISTÓRI- CAS E EDUCATIVAS ${ }^{1}$}

\section{Resumo}

Trata o presente artigo de uma reflexão sobre as potencialidades educativas de determinadas plantas com destaque para aquela que é considerada a planta professora por excelência, a ayahausca, beberagem de origem indígena, também conhecida por uma diversidade de nomes, entre os quais: natema, yagé, nepe, kahi, caapi, nixi pae, shori, kamarampi, cipó, além de daime, vegetal e outros. Resultado de uma pesquisa de natureza teórico-bibliográfica, objetiva-se caracterizar o campo intelectual que envolve essas plantas tidas como ensinadoras, bem como evidenciar suas dimensões psiquícas, históricas e educativas, destacando a ayahuasca entre a diversidade de espécies que conformam a farmacopéia indígena amazônica. Apoiada nos estudos de Henrique Caneiro (2002; 2005) e Escohotado (2004) procuro evidenciar, a histórica circularidade dessas plantas em diversas culturas e sociedades, bem como a influência exercida nos processos de sobrevivência e perpetuação dos saberes grupais. Com Benny Shanon (2002) destaco o profundo impacto cognitivo que exercem na mente das pessoas, bem como a capacidade de mediarem uma multiplicidade de saberes. Palavras-Chave: Plantas professoras, ayahuasca, história, educação. 


\title{
PROFESSOR PLANTS: PSYCHIC, HISTORICAL AND EDUCA- TIONAL DIMENSIONS
}

\begin{abstract}
This manuscript is a reflection on the educational potential of certain plants, especially the one that is considered the professor plant par excellence, the ayahausca, a beverage of indigenous origin, also known for a diversity of names, among which: natema, yagé, nepe, kahi, caapi, nixi pae, shori, kamarampi, cipó, as well as daime, vegetable and others. The result of a research of a theoretical-bibliographical nature, it aims to characterize the intellectual field that involves these plants as professors, as well as to evidence their psychic, historical and educational dimensions, highlighting ayahuasca among the diversity of species that make up the Amazonian indigenous pharmacopoeia. Based on the studies of Henrique Caneiro $(2002,2005)$ and Escohotado (2004), I try to show the historical circularity of these plants in different cultures and societies, as well as the influence exerted in the survival and perpetuation processes of group knowledge. With Benny Shanon (2002), I highlight the profound cognitive impact they have on people's minds as well as the ability to mediate a multiplicity of knowledge.
\end{abstract} Keywords: Professor plants, ayahuasca, history, education. 


\section{PLANTAS MAESTRAS: DIMENSIONES PSIQUICAS, HISTÓRI- CAS Y EDUCATIVAS}

\section{Resumen}

El presente artículo trata de una reflexión sobre las potencialidades educativas de determinadas plantas, destacando la que es considerada la planta maestra por excelencia, la ayahuasca, preparación de origen indígena también conocida por diversidad de nombres como natema, yagé, nepe, kahi, caapi, nixi pae, shori, kamarampi, cipó, además de daime, vegetal, entre otros. Como resultado de una investigación de naturaleza teórico-etnográfica, se busca caracterizar el campo intelectual que encierra a estas plantas consideradas como maestras, así como evidenciar sus dimensiones psíquicas, históricas y educativas, destacando a la ayahuasca entre la diversidad de especies que conforman a la farmacopea indígena amazónica. Apoyada en los estudios de Henrique Caneiro (20022005) y de Escohotado (2004) busco evidenciar la circularidad histórica de esas plantas en diversas culturas y sociedades, al igual que evidenciar la influencia ejercida en los procesos de supervivencia y perpetuación de saberes grupales. Con Benny Shanon (2002) destaco y profundizo en el impacto cognitivo que ejercen en las mentes de las personas, así como la capacidad de mediar en una multiplicidad de saberes.

Palabras clave: Plantas maestras, ayahuasca, historia, educación.

Maria Betânia B. Albuquerque ${ }^{2}$

mbetaniaalbuquerque@,uol.com.br 


\section{INTRODUÇÃO}

Sob certas condições algumas plantas ou 'vegetais' possuidoras de sábios espíritos, teriam a faculdade de "ensinar" às pessoas que os procuram. A ayahuasca - acompanhada sempre do tabaco como planta que possibilita seu manejo - seria uma dessas plantas mestras, porta de entrada que permitiria um conhecimento cada vez maior do mundo natural, em especial do reino vegetal, e que por sua vez indicaria a presença e uso de outras plantas de poder (Luna 2002:181).

Trata o presente artigo de uma reflexão sobre as potencialidades educativas de determinadas plantas com destaque para aquela que é considerada a planta professora por excelência, a ayahuasca, beberagem de origem indígena, também conhecida por uma diversidade de nomes, entre os quais: natema, yagé, nepe, kahi, caapi, nixi pae, shori, kamarampi, cipó, além de daime, vegetal e outros.

Etimologicamente, o termo ayahuasca é originário do dialeto andino quéchua e é formado pelas expressões buasca (cipó) e aya (almas ou espíritos) podendo ser traduzida por "cipó das almas" ou "cipó dos espíritos" (Metzner 2002:1). Cabe ressaltar que o termo pode remeter tanto ao cipó quanto à bebida, preparada a partir de três elementos naturais: O cipó Banisteriopsis caapi (Morton), a folha Psychotria viridis (Ruíz \& Pavón) e água, sendo utilizada tanto por grupos indígenas quanto pela população mestiça ou cabocla da Amazônia. ${ }^{3}$

Sob o ângulo da farmacologia da ayahuasca ${ }^{4}$ o antropólogo Luis Eduar- do Luna (2005) explica que no cipó se encontram dois alcalóides: a harmina e a tetra-hidroharmina. ${ }^{5} \mathrm{Na}$ folha existe um terceiro alcalóide extremamente relevante, pois é ele que possibilita a obtenção de visões por meio das quais é possível vivenciar experiências de aprendizagens. Trata-se da dimetiltriptamina (DMT), a qual:

não é ativa oralmente, sendo desativada no sistema digestivo e no fígado por uma enzima chamada MAO (monoamina oxidasa), que forma parte do sistema de defesa do organismo contra possíveis substâncias tóxicas. A harmina presente na liana [cipó] inibe temporariamente a ação da enzima MAO, possibilitando, assim, que a não desativada DMT atravesse a barreira hematoencefálica (a barreira sangue-cérebro) e chegue até o sistema nervoso central (Luna 2005:335).

Ao sintetizar, "grosso modo", a forma como a ayahuasca atua no corpo humano, Luna (2005:338) esclarece que seu efeito ocorre simultaneamente de duas maneiras:

Os altos índices de serotonina colocam a pessoa em um especial estado de alerta; a ação da DMT no sistema nervoso faz com que o sujeito esteja como que 'sonhando'. Nesse estado, ele pode entrar em extraordinários espaços sensoriais, acessar o que parece ser uma fonte inesgotável de informações, ter estranhas percepções do próprio corpo e de si mesmo, transformar-se em seres não humanos (animais, plantas ou objetos inanimados), ter contato com entidades entendidas como pertencentes a este ou a outros mundos, recordar episódios 
passados ou percebidos subjetivamente como intra-uterinos ou pertencentes à 'vidas passadas', ou ainda ter experiências 'místicas' de muitos tipos.

Ressalta ainda Luna (2005) a grandeza da descoberta da ayahuasca pelas populações amazônicas, considerando uma flora gigantesca e uma mutiplicidade de espécies. Esta grandeza pode explicar o status de sacramento da eucaristia que assume em religiões como o Santo Daime, A Barquinha e a União do Vegetal (UDV) que fazem uso dessa bebida em seus rituais em virtude de potencializar o acesso a essa fonte inesgotável de conhecimentos a que se referiu Luna. ${ }^{6}$

A perspectiva de que certas plantas possibilitam o acesso a conhecimentos conecta-se ao conceito de "plantas mestras" ou "plantas professoras" proposto originalmente por Luna (2002), em seus estudos sobre as práticas de vegetalistas ${ }^{7}$ ribeirinhos que fazem uso da ayahuasca na Amazônia peruana. As "plantas mestras" são "consideradas muitas vezes habitadas por um espírito, por uma mãe, são seres inteligentes, com personalidade própria com quem podemos nos relacionar e aprender" (Goulart et a 2005:34). Foi esta visão das plantas que levou o físico Patrick Druot (200- que conviveu com tribos indígenas na América do Norte e na Oceania - a afirmar que, para os xamãs, os primeiros professores foram as plantas e os animais. Eles foram os primeiros líderes religiosos, os artistas e os médicos.

Em sentido análogo, o historiador italiano Carlo Ginzburg (1989:152), compara o historiador aos primeiros caçadores nas suas buscas por pistas quase imperceptíveis, deixadas pelos animais, que lhes permitissem interpretar a realidade como uma série " $\mathrm{CO}-$ erente de eventos". Desse modo, "o caçador teria sido o primeiro a narrar uma história" e talvez a própria ideia de narração, escreve o autor, "tenha nascido pela primeira vez numa sociedade de caçadores, a partir da experiência de decifração das pistas". A decifração de pistas é entendida como uma metáfora que pode significar "a condensação de um processo histórico que levou, num espaço de tempo talvez longuíssimo, à invenção da escrita". Na trilha dessa analogia de Ginzburg talvez seja possível afirmar que a utilização milenar das plantas professoras, por povos de diferentes culturas, pode significar a gênese do que, contemporaneamente, chamamos de educação. No caso, uma educação mediada pelas plantas, primeiras professoras da humanidade.

Este texto, apoiado em estudos de natureza teórico-bibliográfica, tem por objetivo caracterizar o campo intelectual que envolve essas plantas tidas como professoras, bem como evidenciar suas dimensões psíquicas, históricas e educativas, destacando a ayahuasca entre a diversidade de espécies que conformam a farmacopéia indígena amazônica. Apoiada, entre outros, nos estudos de Henrique Caneiro (2002; 2005) e Antônio Escohotado (2004) procuro evidenciar a histórica circularidade dessas plantas em diversas culturas e sociedades, bem como a influência exercida nos processos de sobrevivência e perpetuação dos sabe- 
res grupais. Com Benny Shanon (2002) destaco o profundo impacto cognitivo que exercem na mente das pessoas, bem como a capacidade da ayahuasca, em particular, de mediar uma mutiplicidade de saberes.

\subsection{Campo das plantas professoras}

O tema das plantas professoras, como é o caso da ayahuasca, está, necessariamente, imbricado com uma variedade de outros campos do conhecimento abrangendo estudos químicos, farmacológicos, botânicos, psicológicos, históricos, antropológicos, literários, artísticos, jurídicos para citar apenas alguns, constituindo as diversas formas de uso dessas plantas em um campo de conhecimento original.

A essa variedade de abordagens se liga também uma diversidade de ambientes culturais de onde tem emanado uma produção intelectual significativa, oriunda de profissionais de diversas partes do Brasil e de outros países, principalmente. $\mathrm{O}$ emaranhado de saberes que envolvem essas plantas dá a elas uma configuração complexa e polissêmica que demanda, por conseguinte, uma perspectiva multidisciplinar para seu enfrentamento. Um primeiro domínio que importa adentrar refere-se aquele ligado à natureza dessas substâncias e as diversas terminologias da qual são investidas - alucinógenas, psicoativas, psicodélicas, enteógenas, entre outras tantas denominações.

O historiador Henrique Carneiro (2002) define as plantas alucinógenas como um grupo específico de plantas psicotrópicas que se diferencia dos sedativos (como o ópio), dos excitantes (como o café e a cocaína), ou dos inebriantes (como o álcool). Os efeitos dessas plantas, segundo o autor, foram chamados pelo farmacologista alemão Ludwig Lewin, de fantásticos, tendo se popularizado com os nomes de alucinógenos ou psicodélicos. Segundo Henrique Carneiro (2005a:58), as características físico-químicas dessas substâncias são:

A muito baixa toxicidade e a também baixíssima dose mínima necessária. Quase não produzem efeito fisiológico, exceto certa midríase (aumento da pupila) e taquicardia. A natureza fundamental do seu efeito é psíquica, esfera que sofre uma ação impactante dessas drogas.

A constatação da existência de uma dimensão psíquica das plantas tornou algumas delas como, por exemplo, o cogumelo teonanactl, o cacto peyote, a ayahuasca e o ololiuqui, substâncias sagradas de diversas religiões americanas. A ação impactante dessas substâncias na psique humana permitiu caracterizá-las como "um tipo especial de substâncias de particulares efeitos psicoativos" (Carneiro 2002:144), isto é, que exercem uma ação sobre a psiquê. $\mathrm{O}$ termo psicoativo engloba, portanto, "o conjunto das plantas e substâncias químicas que agem sobre a mente" (Goulart 2005:30). Tais, substâncias, contudo, embora muito antigas na história da humanidade, só passaram a receber essa denominação no século XX.

Segundo o psiquiatra Charles Grob (2002), existem, aproximadamente, cerca de 150 espécies de plantas alucinógenas que foram utilizadas, em 
algum momento, por diferentes povos da Terra. Parte expressiva dessas espécies (130) encontra-se no chamado novo mundo, isto é, nas Américas, enquanto no velho mundo: Europa, Ásia e África, juntas, são conhecidas apenas 20.

De fato, o novo mundo, escreve Escohotado (2004:12), "conhece dez plantas psicoativas por cada uma das conhecidas no Velho". Tal desigualdade na distribuição global dos psicoativos constitui-se, segundo Carneiro (2002), um fato cultural cujo elemento determinante é o vasto saber herbóreo das populações indígenas existentes nas Américas. A experiência indígena com alucinógenos foi amplamente documentada pelos cronistas da América, uma vez que os fermentados alcoólicos constituíam elemento central da cultura de inúmeros grupos. Entretanto, o termo pelo qual cronistas e viajantes se referiram a essas substâncias era embriaguez não havendo, entre os séculos XVI ao XVIII, uma "consciência dos alucinógenos” (Carneiro 2002:145).

O termo alucinógeno, no contexto da literatura científica, médica e farmacológica, para designar um conjunto de diferentes drogas é recente e agrupa dois grandes tipos: "as psicodélicas, ou seja, o LSD, a mescalina, a psilocibina, a harmina e a harmalina, as triptaminas, como o DMT, e outras diversas moléculas, muitas das quais de recente fabricação sintética" (Carneiro 2002:145). Certas plantas americanas como "o ololiuqui, o peiote e outros cactos, certos cogumelos, a ayahuasca, etc", contém estas substâncias. Há ainda o grupo dos "anticolinérgicos que contém atropina, escopolamina e outros alcalóides, encontrados em plantas como a beladona, a mandrágora, o meimendro, as daturas, etc" (Carneiro 2002:146).

De acordo com o antropólogo Jeremy Narby (apud Carneiro 2002:146), "etimologicamente, o termo hallucinari signifca em latim 'errar com seu espírito, divagar' [...]. É recentemente no século XV que a palavra hallucinari adquiriu o sentido pejorativo de equivocar-se". Carneiro (2002:146) informa que o conceito moderno de alucinação data do século XVII, encontra-se no dicionário francês Le Petit Robert para caracterizar a "percepção patológica de fatos, ou objetos que não existem". Em inglês, no Webster's, o termo caracteriza "falsa ou distorcida percepção de objetos ou eventos..." Em português, no Aurélio, o termo indica "ato ou efeito de alucinar-se; ilusão, devaneio, fantasia; arrebatamento, desvairamento, desvario; percepção aparente de objeto externo não presente no momento, algumas vezes sintoma de desequilíbrio mental".

Devaneio, alucinação, percepção patológica e outras tantas denominações são temas caros às ciências da mente. Os psicoativos assumem, nesse sentido, um papel significativo na constituição histórica da ciência moderna ocidental, em particular na constituição do campo da Psicologia como ciência. Para Carneiro (2002) data do século XIX, os primeiros experimentos de pesquisas com tais substâncias. Destaca-se a investigação sobre o óxido nitroso, chamado gás hilariante, a partir do consumo pessoal do filósofo norte americano William James que culmi- 
nou na elaboração da obra Variedades da experiência religiosa (1902).

James, que segundo Shanon (2002:639) foi "um dos grandes pais da psicologia cognitiva", se interessava pelos aspectos relacionados à multiplicidade $\mathrm{e}$ complexidade da consciência, investigando, ainda, suas dimensões paranormais e místicas consideradas à margem das fronteiras da ciência. Para James (apud Shanon 2002:639):

Nossa consciência normal quando estamos acordados, consciência racional como a chamamos, é apenas um tipo especial de consciência, espalhando-se sobre ela, apartadas dela pela mais fina das telas, encontram-se formas potenciais da consciência inteiramente diferentes. Nós podemos ir através da vida sem suspeitar a sua existência; mas aplicando o estímulo requisitado e disponível elas estão lá em toda sua completude, tipos definidos de mentalidade que provavelmente, em algum lugar, têm seu tipo de aplicação e adaptação. Nenhuma apreensão do universo, em sua totalidade, pode ser final ao deixar estas outras formas de consciência bastante ignoradas.

Goulart et al (2005:39-0), referindo-se à relação existente entre o estudo dos psicoativos e a ciência moderna acrescentam que:

De certa forma, a experiência oitocentista das drogas contribui para fundar a psicologia na medida em que fornece um instrumento de produção de diferentes estados de consciência, os quais permitiriam uma observação do 'eu', ou melhor do 'si próprio', como nunca antes alcançada. É assim que os espíritos curiosos sobre si mesmos serão seduzidos incessantemente, por esta via das substâncias psicoativas, para o autoconhecimento. A atitude experimental diante da consciência inaugura uma ciência cujo objeto é o próprio sujeito observador, e os instrumentos produtores dos estados de percepção possibilitam ampliar a gama e mesmo as distinções entre os três tipos básicos de consciência: vigília, sono e sonho. O ópio e o haxixe trazem o sonho para a vigília, confundindo-os num novo estado. Os anestésicos trazem o sono para a vigília, anulando-a quimicamente de uma forma tão absoluta que se tornaram possíveis as intervenções cirúrgicas indolores.

Vale ressaltar, também, no âmbito das experiências científicas com psicoativos, os estudos de Sigmund Freud, "um dos primeiros a teorizar sobre o papel das drogas psicoativas na economia da libido, identificando-as como o mais eficaz mecanismo de obtenção do prazer e de afastamento da dor" (Goulart et al. 2005:39-0).

No início do século XX, com o isolamento da mescalina a partir do cacto peyote (1897) por Arthur Heffter e, posteriormente, seu processo de sintetização em laboratório (1919), por Ernst Späth, "difundiram-se diversas experiências de cientistas, psicólogos, escritores e artistas com esta droga" (Carneiro 2005:59). Na década de 1930, destacam-se, sobretudo, os estudos de Heinrich Kluver, na Alemanha, sobre a mescalina, ${ }^{8}$ atraindo interesses de intelectuais como Jean-Paul Sartre que após tomar essa substância escreveu as obras $A$ Náusea e a Imaginação. 
Heinrich Kluver realizou uma tipologia dos arquétipos provocados pela mescalina, em especial os efeitos visuais (grade, treliça, trama, cordas, filigrana, favos de abelha, enxadrezado, teia de aranha, túnel, funil, viela, cone, barco, espiral). Entretanto, segundo Carneiro (2002:139), os estudos pioneiros desse período se limitam a "enfoques parcelares e laboratoriais de uma experiência cuja natureza múltipla, polissêmica e subjetiva tornava-se inabordável pelos métodos e testes psicológicos tradicionais destinados a verificar 'alucinações visuais"”.

Para Carneiro (2002:138), data de 1924 a publicação de Phantastica, "obra mais influente na classificação das substancias psicoativas", na qual Ludwig Lewin classificou essas substâncias em cinco tipos: fantásticas, excitantes, sedativas, euforizantes e inebriantes. Posteriormente, essa classificação evoluiu para três tipos que englobavam: os depressores, os estimulantes e os alteradores da consciência. As substâncias do tipo fantásticas foram denominadas, segundo Lewin, de alucinógenas, conceito este que prevaleceu para classificar as plantas como o peyote e a ayahuasca. O termo alucinógeno, de 1930 a 1950, e ainda hoje, é "considerado científico para descrever em termos farmacológicos os efeitos de uma gama de substâncias que vão da maconha ao LSD" (Carneiro 2005a:63).

Além de alucinógeno, há ainda os que utilizam o termo psicodélico, um neologismo derivado do grego, "literalmente que manifesta a psique" (Fontes 2008:13). Trata-se de uma denominação cunhada pelo psiquia- tra canadense Humphry Osmond, em 1955, numa troca de correspondência com o escritor britânico Aldous Huxley, que também participou da construção do termo. Amplamente adotado pelo movimento político cultural dos anos 60, o termo é, segundo Carneiro (2005:63), "mais estético, mais preciso semanticamente, e imbuído de um conteúdo político e laico".

Típico dos anos 60, o "movimento psicodélico" surgiu inserido num contexto de amplas manifestações contraculturais, como no caso do movimento feminista ou de homossexuais, entre outros, cujas reivindicações pautavam-se na luta pela "livre disposição do corpo e de autonomia sobre si próprio" (Carneiro 2005a:67). Ele representou

uma defesa política da autonomia sobre a intervenção psicoquímica voluntária contra a política oficial do proibicionismo estatal, caracterizado como Inquisição farmacrática contra o direito de escolha na estimulação química do espírito (Carneiro 2005a:67).

Utilizando-se do amplo arsenal de que é constituído o saber herbário, bem como das tecnologias psico-farmacoquímicas disponíveis, o que estava em jogo era o direito dos seres humanos à busca socrática do conhecimento de si mesmo. Entretanto, a resposta política do ocidente a essas reivindicações "pelas chaves vegetais e químicas da consciência", segundo o historiador, foi até hoje negativa (Carneiro 2005a:67). O apogeu desta contracultura coincide, em linhas gerais, 
com a sociedade industrial 'afluente', cujo superavit econômico permite que milhões de jovens se lancem em peregrinação pelo mundo e outros tantos se marginalizem sem deslocação geográfica, preferindo viver das abundantes sobras a morder os iscos do consumismo; 1968, momento de auge na cosnciência desse superavit, será também o ano em que explodem as grandes revoltas estudantis nos Estados Unidos e na Europa (Escohotado 2004:150).

No contexto contracultural, o nome de Aldous Huxley é uma referência, cuja iniciação nos mistérios da mescalina marcou "O advento da revolução psicadélica moderna” (Fontes 2008:11). Seu interesse pelo tema, afirma o autor, fora despertada em 1931 por ocasião da leitura de "Phantástica" de Ludwig Lewin, num momento em que as chamadas drogas visionárias eram ainda desconhecidas da ciência ocidental.

A experiência visionária de Huxley deu origem ao seu $40^{\circ}$ livro: As Portas da Percepção (1954), forjado a partir do relatório da sessão de mescalina que ingeriu das mãos do psiquiatra britânico Humphry Osmond para quem, posteriormente, apresentou o relatório. Em 1956, Huxley deu seguimento ao livro publicando Céu e Inferno, um curto ensaio "em que aborda as vertentes antropológicas e culturais da experiência visionária da mescalina" (Fontes 2008:12). A publicação de As Portas da Percepção, segundo Fontes, obteve sucesso imediato causando, também, inúmeras controvérsias e reunindo inúmeros adeptos:

As Portas da Percepção encontraria o seu público de eleição nas subcultu- ras emergentes no mundo ocidental que rejeitavam o conformismo e consumismo do 'admirável mundo novo’ pós-II Guerra Mundial. É difícil exagerar a influência que o 'livrinho' de Huxley teve na geração bet dos anos 50 e no movimento hippie que lhe sucedeu nos anos 60 - Jack Kerouac, Allan Ginsberg, Timothy Leary, Terence McKenna e Carlos Castaneda contam-se entre as figuras contraculturais de proa que garantiram que 'tudo começou' com a leitura de As Portas da Percepção (Fontes 2008:12).

Assim, tanto As portas da percepção quanto Céu e Inferno se configuraram como "desbravamento pioneiro de um novo campo epistemológico, quando se difundiu o LSD, ${ }^{9}$ descoberto acidentalmente pelo químico suíço Albert Hoffamn em 1943" (Carneiro 2005a:59). O projeto de Huxley era ousado, mas, na sua percepção, necessário a uma sociedade com um ritmo acelerado de desenvolvimento tecnológico, consumismo e hostil às revelações místicas. Huxley estava convencido de que a integração de substâncias psicoativas nos rituais sociais humanos era uma estratégia em prol do bem-estar da espécie humana em face aos desafios apocalípticos que se lhe deparavam. Entretanto, o mais inusitado foi a proposição, a que se dedicou por toda vida, de um projeto educativo mediado pelos psicoativos ou, de outro modo, de uma educação psicodélica em que advogava os benefícios terapêuticos e educativos dos psicodélicos na conformação de uma sociedade menos embrutecida.

Em seu romance derradeiro, $A$ ilha (1962), Huxley expõe sua utopia de 
uma sociedade ideal na qual os psicodélicos desempenham um papel estruturador de uma vida baseada na harmonia individual, social e ecológica. Nas suas palavras:

Em $A$ itha especulei em termos ficcionais sobre o modo como uma substância semelhante à psilocibina possa ser usada para potenciar a educação não verbal dos adolescentes e recordar aos adultos que o mundo real é muito diferente do universo deformado que criaram para si próprios através dos seus preconceitos culturalmente condicionados (Huxley apud Fontes 2008:19).

Como "terapia psicodélica de choque à cultura humana", os psicodélicos configuravam-se como agentes químicos de expansão da consciência fundamentais à construção de outras formas de vida. O termo, afirma Fontes (2008:14), tem esse significado até a última década do século XX, quando passou a ser preterido pelo termo 'enteógeno', ou seja, "que manifesta a divindade interior".

A expressão enteógeno liga-se ao norte-americano Gordon Wasson. Em 1955, Wasson desenvolveu uma vasta investigação etnobotânica e histórico-antropológica dos alucinógenos (os cogumelos psilocibe mexicano, o teonanactl, o amanita muscária siberiano, o soma indiano, entre outros) e compreendeu esses fenômenos como "partes de uma vasta tradição planetária de uso de alucinógenos" (Carneiro 2002:140). Um ponto a destacar destes estudos foi a proposição, no final da década de setenta, por Wasson e colaboradores, da expressão enteógenos para caracterizar as substâncias de natureza alucinógena. $\mathrm{O}$ termo enteógeno deriva do grego antigo, entheos, e é utilizado para

descrever o estado em que alguém se encontra quando inspirado por um deus que entrou em seu corpo. Era aplicado aos transes proféticos, à paixão erótica e à criação artísti$\mathrm{ca}$, assim como aos ritos religiosos onde estados místicos eram experienciados através da ingestão de substâncias que partilhavam da essência divina. Portanto, enteógeno significa aquilo que leva alguém a ter o divino dentro de si (Macrae 1992:16).

Entretanto, a maior parte dos estudos médicos, farmacológicos e sociológicos sobre droga, em âmbito internacional, não aderiu a nomenclatura enteógeno, prevalecendo o termo alucinógeno. Isto porque, explica Jeremy Narby (apud Carneiro 2002:140), o neologismo enteógeno "só representa uma carga maior de jargão para um tema já difícil e porque acrescenta conotações divinas (Theos = Deus) desnecessárias". Por sua vez, o termo alucinógeno é marcado pela impropriedade, pois, segundo Homann e Schultes (apud Carneiro 2002), estudos recentes demonstraram que os efeitos psicofisiológicos são tão complexos, que este termo não alcança toda a gama de reações, além de "enfatizar apenas as alterações perceptivas, em detrimento daquelas afetivas e intelectivas, que também caracterizariam os efeitos destas substâncias" (Goulart et al. 2005:31).

Nos séculos XX e XXI, muitos estudiosos têm, contudo, optado pelo termo enteógeno como forma de se contrapor ao sentido pejorativo que o termo alucinógeno encerra, isto é, como erro, 
engano, loucura. O termo alucinógeno é rechaçado uma vez que não permite compreender "os beatíficos e transcendentes estados de comunhão com as divindades que, segundo a crença de muitos povos, determinados indivíduos podem alcançar mediante a ingestão dos psicoativos" (Macrae 1992:16).

As conclusões de Gordon Wasson embasadas em sua própria experiência com as cerimônias sagradas do cogumelo no México - causaram, segundo Carneiro (2005:74), grande impacto nos círculos acadêmicos, pois, "pela primeira vez se apresentava uma tese global justificada com sérias investigações que afirmava a ligação indissolúvel entre drogas e religião".

A partir do uso boreal do cogumelo siberiano Amanita muscaria, Wasson desenvolveu a tese de uma proto-religião baseada no uso dos cogumelos que teria se propagado com as invasões indo-arianas, nas formas do soma hindu e do haoma persa. O cristianismo, no entanto, elevou o vinho à condição de única droga sagrada e baniu todas as demais, proibindo o ópio, os ritos de Elêusis, os usos de plantas curativas pelos camponeses e as práticas vegetais de todos os paganismos. Tal restrição a certas plantas se inscreve até mesmo na mitologia teogônica do Gênesis com as árvores dos frutos proibidos (Carneiro 2005a:745).

A constatação de uma relação entre drogas e religião induziu a uma compreensão dos psicoativos como potencializadores de experiências místicas e espirituais. Nessa direção, destacam-se os estudos do psicólogo norte ameri- cano Timothy Leary, considerado "O papa do psicodelismo e do uso do ácido lisérgico" (Macrae 1992:17) o qual, segundo Metzner (2002), devotou parte significativa de sua vida à investigação das dimensões espirituais da experiência psicodélica. De acordo com Metzner (2002:24-5):

Depois de levarem avante suas pesquisas pelas muitas experiências com psicodélicos, os psicólogos ocidentais chegaram a conclusões semelhantes às dos exploradores xamanísticos da Amazônia e do antigo México; em ambas abordagens existe o reconhecimento da possibilidade de cura e da resolução dos problemas e dificuldades pessoais, especialmente em relação aos padrões de culpa e medo que estejam interligados com a sexualidade e o nascimento. Porém, tão logo se alcança um nível mais profundo, verifica-se que tais experiências permitem acesso às esferas mais transcendentes e místicas do fenômeno humano, passando a nos ensinar um sem número de lições relativas ao nosso passado remoto, à nossa origem, ao nosso envolvimento com os reinos espirituais, e ao nosso possível futuro.

Entre outros, Timothy Leary foi fortemente influenciado pela leitura de "As Portas da Percepção" de Huxley, que também teve "a sua própria epifania psicadélica por efeito de cogumelos psico-activos no México", os quais haviam sido descobertos por Gordon e Valentina Wasson, na remota província mexicana de Oaxaca, onde milenarmente eram utilizados em rituais xamânicos (Fontes 2008:16). 
O encontro de Huxley e Leary em 1960, por ocasião das conferências que Huxley proferira no Massachusetts Institute of Technology, foi a ocasião propícia para ser colocado em ação um projeto concebido por Huxley e colaboradores que visava ministrar mescalina a uma centena de cientistas e intelectuais. Apresentado à Fundação Ford e imediatamente recusado, o projeto tinha como objetivos testar as reações dessas pessoas à experiência visionária (Fontes 2008).

O "Projeto Psilocibina", lançado em 1960 na Universidade de Harvard onde se encontrava o psicólogo Timothy Leary, e sob a direção deste, tinha o objetivo de testar o potencial da psilocibina sintética (e posteriormente o LSD) na personalidade e na criatividade. Segundo Fontes (2008:16), este projeto

Viria a consagrar-se como o epicentro da revolução psicodélica ao iniciar nas drogas visionárias figuras como Jack Kerouac, Allan Watts e Allan Ginsberg - isto antes do programa ter sido cancelado em 1963, na sequência do alarme que as heterodoxas investigações psicodélicas causaram entre os membros mais conservadores de Harvard.

Timothy Leary (2001:40) estabelecia uma íntima conexão entre piscodélicos, espiritualidade e ciência afirmando existir uma "evidência fenomenológica obsessiva que insghts espirituais acompanhando a experiência psicodélica sejam descrições subjetivas das descobertas objetivas da astronomia, da física, da bioquímica e da neurologia". Para ele, os psicodélicos, (o LSD, a mescalina e a psilocibina) possibilitam o acesso "à teia de bilhões de células e impulsos elétricos e produzem novas impressões ou novas realidades". A produção de novas realidades pelo cérebro, induzidas pelos psicodélicos, enquanto drogas que "manifestam a mente", permitia que se observasse a natureza neuroelétrica da consciência e isto, para Leary, significava uma revelação ontológica consubstanciada no fato de que "o cérebro fabrica realidades” (Leary 2001:39). A propósito do Projeto Psilocibina dizia:

O primeiro objetivo do Projeto de Pesquisa de Harvard em Drogas Psicodélicas era o de treinar cientistas-técnicos no uso de poderosos químicos que mudam o cérebro. O LSD nos proveu um método de mudar a consciência e a função cerebral - a ferramenta que filósofos e psicólogos anteciparam por séculos (Leary 2001:42).

Na década de 1960, Timothy Leary foi o responsável pelo estabelecimento de uma classificação, amplamente conhecida entre os estudiosos dos psicoativos. Trata-se da hipótese do cenário segundo a qual "as determinantes primárias da experiência psicodélica encontram-se, simultaneamente, no cenário interno (intenção, expectativa e motivação) e externo, isto é, no contexto, além de incluírem a presença do guia ou terapeuta" (Metzner 2002:21-2).

Ao considerarem as práticas tradicionais xamânicas, Timothy Lery e seu colaborador, Ralph Metzner, observaram que essas experiências atentavam para detalhes importantes do cenário como a "música de fundo, a comida apropriada e enfatizavam a 
necessidade de uma pessoa experiente assumir o papel de guia, exercendo a função de xamã, conduzindo a sessão e evitando as bad trips (viagens ruins)" (Macrae 1992:17). Leary voltava-se, especialmente, para pessoas sem experiência no uso de psicoativos, para o que recomendava a necessidade de uma preparação pessoal e um ambiente adequado à experiência. Quanto melhor a preparação, dizia, "mais extasiante e reveladora é a sessão". A preparação pessoal refere-se

à história pessoal, tolerância da personalidade, ao tipo de pessoa que você é. Seus medos, seus desejos, seus conflitos, culpas, paixões secretas, determinam como você interpreta e manuseia qualquer experiência psicodélica (Leary 2001:44)

Quanto ao ambiente, enfatiza a importância dele estar "removido dos usuais jogos interpessoais, e o mais livre possível de distrações e intromissões inesperadas". Durante a experiência psicodélica, "o viajante deve ter certeza de que ele(a) não será perturbado" a fim de se evitar "produzir um choque na atividade alucinatória". Assim, "confiança no que está em sua volta e privacidade são necessárias" (Leary 2001:44).

Como o mestre Aldous Huxley, as ideias de Leary também comportam uma perspectiva de educação pelos psicoativos. Leary estabelecia estreita ligação entre inteligência, ciência e divindade (Deus). Para ele, a inteligência é Deus assim como Deus é pura manifestação da inteligência e que, portanto, habita dentro de cada DNA. O pro- jeto de Leary era alterar quimicamente o cérebro para elevar a inteligência e, assim, permitir encontrar Deus. Nas suas palavras:

os humanos fabricam e mantém seus próprios mundos pessoais. Por volta de 1966 essa mensagem de auto-responsabilidade foi expandida da secção interpessoal para a neurológica. Suas ações determinavam o ambiente que você habitava. A divindade estava dentro de cada um e a palavra "Deus" era entendida para se referir à Inteligência Elevada residente dentro do cérebro de cada um e dentro de cada DNA. $\mathrm{O}$ alvo era o de prover uma razão socialmente aceitável para alterar o seu próprio cérebro e elevar a inteligência (Leary 2001:72).

$\mathrm{Na}$ efervescência intelectual dos anos sessenta, vale ainda lembrar que os estados de ampliação da percepção, produzidos por determinados psicoativos, foram bastante popularizados pelos livros do antropólogo Carlos Castaneda. A partir de suas experiências pessoais com psicoativos, Castaneda afirma seus poderes como veículos para a aquisição de um conjunto de conhecimentos sobre a realidade, capazes de transformar o iniciado em "um homem de conhecimento" (Goulart et al. 2005:33).

Nos anos de 1989, o trabalho sobre os direitos territoriais dos índios da Amazônia levou o antropólogo Jeremy Narby a visitar os Ashanincas, os Aguaruna, Shipibo, Shawi entre outros grupos. Durante essas viagens, perguntou a eles como aprenderam o vasto conhecimento que tinham acerca das plantas e todos eles lhe deram a mesma 
resposta: "o conhecimento a respeito das plantas vem dos ayahuasqueros e tabaqueiros, que ingerem suas misturas de plantas e falam em suas visões com as essências comuns a todas as formas de vida" (Narby 2004:4).

A despeito da diversidade territorial das plantas professoras, Edward MacRae (1992:35) afirma que "é nas Américas que se concentra o maior número dessas substâncias, e onde até hoje mais frequentemente se faz uso delas". De acordo com Metzner (2002:203):

As sociedades tribais fazem uso destas plantas e preparados vegetais porque os vêem incorporados por seres de consciência inteligente, somente perceptíveis pelos estados especiais da consciência, capazes de funcionar como mestres espirituais e ricas fontes de poder de cura e de conhecimento.

Embora o ritual de consumo das plantas esteja envolto em várias dimensões chamo atenção para as suas dimensões sagradas, divinatórias, medicinais e, fundamentalmente, pedagógicas, pois, como afirma um ditado mexicano, "qualquer coisa que uma pessoa queira saber, os espíritos do cogumelo responderão" (Furst 1989:14). Em função dessas potencialidades, as plantas professoras, fazem-se presentes em diferentes culturas, no mundo inteiro, e exercem grande influência nos processos de sobrevivência e perpetuação dos saberes grupais. O consumo milenar das plantas e substâncias psicoativas em diferentes espaços e culturas constitui, assim, um instigante objeto para a historiografia. Mas plantas têm história?

\subsection{As plantas professoras na história}

O historiador Peter Burke (2005:48), referindo-se à abordagem proposta pela história cultural, afirma que "estamos a caminho da história cultural de tudo: sonhos, comidas, emoções, viagens, memória, gesto, humor", dentre outros. Nesta listagem também é possível inserir as plantas e beberagens feitas a partir delas.

Para citar um exemplo que remete à historicidade das plantas, basta recorrer à história daquela que causou, nos séculos XVI e XVII, debates acalorados entre cronistas, viajantes e missionários que andaram pelo novo mundo: a mandioca. De acordo com o historiador Ronaldo Vainfas (2000), a mandioca era cultivada em todas as searas da colônia, tornando-se, posteriormente, parte da culinária africana. Considerada o pão dos trópicos, ela alimentava índios e brancos, substituindo o trigo na mesa dos primeiros colonos. As receitas de mandioca foram logo assimiladas pelos europeus, constituindo-se no principal mantimento no período colonial.

Contudo, ao lado de suas virtudes alimentícias, a mandioca guardava ainda dimensões místicas e religiosas, pois, de acordo com missionários e colonos, tais raízes eram desconhecidas entre os índios da América e teria sido o apóstolo de Jesus, Tomé, quem, em uma viagem mítica, difundiu o produto dando início ao processo de conversão dos gentios. Todavia, nem sempre a mandioca conduzia os ameríndios ao caminho de Deus, pois a mesma raiz era utilizada em ritos considerados 
abomináveis, entre os quais as práticas de beberagens, ocasião em que os índios consumiam o canim, bebida fermentada embriagante feita de mandioca e outros produtos. Por conta disso, a mandioca tornou-se um tema debatido entre cronistas e viajantes, uma vez que ora alimentava cristãos, ora conduzia os índios ao estado de embriaguez alcoólica, aproximando-os do demônio.

Em meados do século XVII, o jesuíta português João Daniel contestou o uso da mandioca entre os índios da Amazônia. Segundo ele, tais raízes eram responsáveis pelo atraso da agricultura além de induzirem os índios a resistirem aos costumes cristãos. Em vista disso, advogava seu completo desterro (Vainfas 2000), isto é, a eliminação destas práticas de cultivo.

Uma beberagem como a ayahuasca, também está envolta em uma teia complexa de saberes. Mas, por ora, cabe apenas lembrar que as plantas professoras estavam e estão presentes nas práticas culturais de inúmeros grupos humanos. Nas culturas de caçadores-coletores, afirma o historiador espanhol Antônio Escohotado (2004:10), “os sujeitos aprendem e a reafirmam sua identidade cultural passando por experiências com alguma droga psicoativa", antecipando o que seria denominado posteriormente pelas religiões sedentárias, como verdade "revelada".

Antes de o sobrenatural se concentrar em dogmas escritos, e de castas sacerdotais interpretarem a vontade de qualquer deus único e onipotente, o fulcro de inúmeros cultos era o que se percebia em estados de consciência alterada, e foi-o preci- samente a título de conhecimento revelado. As primeiras hóstias ou formas sagradas eram substâncias psicoativas, como o peyotl, o vinho ou certos cogumelos (Escohotado 2004:10-1).

Nesses tempos primordiais, as plantas psicoativas eram inseparáveis dos domínios da medicina, da religião e da magia, sendo os xamãs, "a mais antiga fusão dessas três dimensões" (Escohotado 2004:12). O xamanismo, segundo este historiador, é

uma instituição originalmente difundida por todo o planeta, cujo sentido é ministrar técnicas de êxtase, entendendo-se por êxtase um transe que elimina as barreiras entre a vigília e o sonho, o céu e o subsolo, a vida e a morte. Tomando uma droga, ou dando-a a outro - ou a toda a tribo -, o xamã (homem ou mulher) lança uma ponte entre o comum e o extraordinário, que serve tanto para a adivinhação mágica como para cerimônias religiosas e para a terapia (Escohotado 2004:12).

Em um olhar "elementar" sobre a história das plantas psicoativas na antiguidade remota, Antônio Escohotado (2004:15), afirma que o ópio egípcio surge mencionado na Odisséia por Homero como coisa que "faz esquecer qualquer sofrer". Na China, foram achados os primeiros restos da fibra de Cânhamo datados de 4.000 a.C. Um tratado chinês de medicina, escrito no século I afirma que "o cânhamo tomado em excesso faz ver monstros, mas se se usar muito tempo pode comunicar com os espíritos e aligeirar o corpo" (apud Escohotado 2004:16). Na 
Índia, seu consumo é "imemorial" e, segundo a tradição brâmane, ele "agiliza a mente, conferindo longa vida e desejos sexuais potenciados" (Escohotado 2004:16).

Também na África é conhecida a Iboga, de onde se extrai uma bebida consumida no Gabão e no Congo no culto Buiti. No Buiti existem dois ritos principais: as cerimônias noturnas (ngozé) e o rito de iniciação (tobe si). As ngozé são uma espécie de "missa" coletiva, na qual todos os participantes ingerem como forma de comunhão uma dose de raiz pulverizada de iboga, passando a noite dançando e cantando seguindo um ritual específico. $\mathrm{O}$ rito de iniciação é celebrado toda vez que um indivíduo decide se tornar membro da comunidade religiosa. Nesse caso, o iniciando ingere certa quantidade de raiz de iboga que o leva gradualmente à perda da consciência, momento em que sua alma sai do corpo e efetua uma "viagem ao além" entrando em contato com entidades divinas que o iluminam, revelando-lhe as "raízes da vida" (Samorini 2005:309).

Referindo-se às plantas visionárias, Antônio Escohotado (2004) afirma que na América, em povoamentos pré-agrícolas do sétimo milênio anterior à nossa era, já existiam sementes correspondentes a essas plantas:

A partir do século $\mathrm{X}$ a. C. há cogumelos de pedra entre os monumentos da cultura de Izapa, na atual Guatemala, que continuaram a ser esculpidos por diferentes pontos da América Central durante mais de mil anos. É também ao século $\mathrm{X}$ a.C. que remontam divindades da cultura chavin, cuja sede foi o atual Peru, que em certos entalhes de pedra seguram um cacto visionário. $\mathrm{E}$ ao século IV a.C pertence um cachimbo em cerâmica com forma de veado, que tem entre os dentes um botão de peiotl (Escohotado 2004:18).

O historiador francês Serge Gruzinski o qual, segundo Carneiro (2002:174), "é um dos poucos que se dedicou a estudar esse tema", ao analisar a colonização mexicana, nos séculos XVI a XVIII, destaca o lugar privilegiado dos alucinógenos como parte de um complexo cultural milenar. No período pré-hispânico, diz o autor:

Os alucinógenos faziam parte dos grandes rituais como a 'festa das revelações' entre os mexicas, os banquetes principescos, os sacrifícios, as adivinhações e a medicina. Seu consumo era uma atividade altamente valorizada, cuidadosamente codificada, contida por regras que deviam ser imperiosamente observadas e cuja infração era punida (Gruzinski 2003:315).

Extremamente antiga, a arte de adivinhar remonta a um tipo de saber conhecido como "divinatório" caracterizado pela "capacidade de, a partir de dados aparentemente negligenciáveis, remontar a uma realidade complexa não experimentável diretamente" (Ginzburg 1989:152). É o caso, por exemplo, dos textos divinatórios da Mesopotâmia escritos a partir do terceiro milênio a. C., em que as divindades tinham entre suas atribuições a tarefa de "se comunicar com os súditos por meio de mensagens escritas - nos astros, nos corpos humanos, em toda 
parte -, que os adivinhos tinham a tarefa de decifrar" (Ginzburg 1989:153).

Entretanto, alerta Henrique Carneiro a despeito da importância divinatória, medicinal e religiosa dos alucinógenos no complexo cultural de diferentes grupos humanos, o seu papel na cultura material da humanidade não tem sido suficientemente enfatizado. Para se ter uma ideia da sua relevância na constituição da economia moderna, basta lembrar que "o Brasil obteve a maior parte dos escravos africanos por escambo direto com a África, onde se trocavam homens por tabaco e aguardente" (Carneiro 2005b:17).

Contudo, cabe observar que no contexto colonial a palavra droga não possuía o sentido negativo relacionado ao vício a qual, constantemente, é atrelada na contemporaneidade. Antes, ela significava "um conjunto de riquezas exóticas, produtos de luxo destinado ao consumo, ao uso médico e também como 'adubo' da alimentação, termo pelo qual se definiam o que hoje chamamos especiarias" (Carneiro 2005b:14).

No Diccionário da Lingua Portugueza Recopilada de Antônio de Moraes Silva, a palavra é definida como constituindo "todo o gênero de especiaria aromática; tintas, óleos, raízes oficiais de tinturaria, e botica. Mercadorias ligeiras de lã, ou seda" (Carneiro 2005b:10). Desse modo, na sociedade colonial não havia uma distinção clara entre drogas e alimentos, diferindo radicalmente de nossa época onde "as fronteiras entre esses dois conceitos são muito bem definidas e bem vigiadas" (Carneiro 2005b:15). Essa vigilância recai, entretanto, não no papel das drogas como alimentos para o corpo, mas, sobretudo, no papel que exercem na produção dos chamados estados de êxtase, proporcionados pela ingestão de determinadas substâncias:

Ópio, cannabis, cogumelos, cactos, todas as formas de consumo do álcool, tabaco, café e chá são algumas dessas substâncias e plantas que têm uma importância se não igual, superior às plantas alimentícias, pois as drogas são alimentos espirituais, que consolam, anestesiam, estimulam, produzem êxtases místicos, prazer intenso e, por isso, instrumentos privilegiados de sociabilidade em rituais festivos, profanos ou religiosos (Carneiro 2005b:15-6).

Henrique Carneiro (2002) em Amores e sonhos da flora: afrodisíacos e alucinógenos na botânica e na farmácia, ao realizar uma história moral da farmácia, evidencia os significados culturais atribuídos às diferentes drogas, esclarecendo as íntimas conexões existentes entre o uso de determinadas plantas e o prazer sexual, fato que deu origem a um intenso aparato de intervenção e regulação dessas práticas. Segundo Carneiro, foi com espanto que os europeus tomaram contato com a farmacopéia indígena, constituída por poderosas plantas alucinógenas, até então desconhecidas, cuja embriaguez provocada incitava a diversos desvios e transgressões morais tais como os "pecados da carne" e a luxúria de um modo geral.

Tomada como idolatria, a embriaguez - "grade conceitual com a qual o Oci- 
dente encarou o consumo de diversas substâncias e o domínio de um múltiplo arsenal de técnicas do êxtase na América" (Carneiro 2002:176) - foi o alvo central de intensa campanha da Igreja contra o saber herbóreo indígena, cujo domínio era infinitamente superior ao dos europeus. Nessa perspectiva,

Muito mais do que as mortes ou ferimentos provocados por brigas entre bêbados, o que mais preocupava as disposições coloniais sobre o comportamento indígena de embriagar-se era que isso levava-os a 'idolatrarem', 'adorarem as huacas' tornando-se apóstatas da fé cristã, além de cometerem o pecado do adultério. São essas 'ofensas a Deus’ as razões maiores da repressão católica às formas de embriaguez indígena (Carneiro 2002:182).

Por conta disso, a instituição do Santo Ofício da Inquisição, em 1571, teve como uma de suas principais finalidades "impedir a contaminação dos europeus e mestiços pela cultura indígena" (Carneiro 2002:173). Entretanto, "sua eficácia como instrumento contra-aculturativo" nem sempre surtiu o efeito desejado posto que essas práticas se alastraram para além dos domínios dos conquistadores. Segundo o autor:

No choque cultural entre os conquistadores espanhóis e os indígenas nas Américas, destacou-se a influência da medicina nativa e, sobretudo, do uso de alucinógenos. Embora não possamos separar domínios estanques na cultura indígena chamando-os de 'religião', 'medicina' ou 'estado', podemos afirmar que os europeus puderam rechaçar conscientemente, da forma mais violenta, as instituições e crenças das religiões indígenas, mas o conhecimento nativo médico e botânico, assim como a sua alimentação, penetrou intersticialmente por entre os dominadores (Carneiro 2002:173-4).

Uma perspectiva política da história das plantas psicoativas evidencia que onde seu uso era considerado essencial, a presença repressiva do colonizador fazia-se sentir. Furst (1989), referindo-se ao processo de colonização mexicana pelos espanhóis, menciona um julgamento presidido por um frade franciscano, de dois irmãos índios, ocorrido em 1537, na Cidade do México. Dentre as acusações, constava a invocação aos deuses de sua religião e o consumo de cogumelos. Para o autor, eliminar quaisquer vestígios da religião pagã era uma determinação dos colonizadores espanhóis, os quais "ficavam particularmente irritados com a persistência teimosa com que os índios veneravam as plantas alucinógenas - os cogumelos, as sementes da trepadeira ipoméia [...], o cacto peiote e outras espécies psicotrópicas” (Furst 1989:71-2).

O consumo do cacto peiote, por exemplo, foi reconhecido pelos espanhóis tão logo chegaram à América, tendo sido associado "aos rituais de sangue dos astecas" pelo que lhe deram o nome de "raiz do demônio" (Richardson 1988:40). No caso específico da colonização mexicana, Serge Gruzinski (2003:316), informa que:

O recurso aos alucinógenos provocava repulsa e temor dos evan- 
gelizadores. Quando estes não censuravam as informações assim obtidas, tratavam de fornecer, em palavras e imagens, uma interpretação demoníaca das visões produzidas pelo consumo das plantas. Acusavam os alucinógenos de serem instrumentos de Satanás e também de levarem à loucura passageira ou definitiva, à embriaguez comparável à alcoólica, e inclusive à luxúria.

A colonização européia brasileira, como se sabe, também foi marcada pelo choque cultural e pela luta dos colonizadores contra os costumes locais, muitos dos quais interpretados como coisas demoníacas, numa transposição do imaginário europeu à nova colônia. Segundo a historiadora Laura de Melo e Souza (1986:42-3), a despeito do predomínio da visão edênica do descobrimento como fruto de uma ação divina, desencadeada por uma nação ela mesma escolhida por Deus (Portugal), "havia também uma visão detratora da América que lhe procura reforçar os aspectos negativos". Para a autora, à medida que o novo continente emergia na sua especificidade, a edenização ficou ameaçada. Eram "novas plantas, ventos fortes, chuvaradas, mas, sobretudo, homens e bichos estranhíssimos, outros que os europeus" (Souza 1986:61). Para o europeu católico, “a humanidade anti-humana" da gente nativa se evidenciava, entre outras coisas, pelo estado de pecado em que viviam. Dentre as práticas pecaminosas e, portanto, repudiadas, estava o consumo de bebidas fermentadas, as quais, entre outras finalidades, "eram parte integrante da dieta e uma im- portante fonte de nutrientes essenciais" (Fernandes 2005:54).

A perseguição ao consumo do cauim, uma prática central entre os índios Tupinambá, por exemplo, é um exemplo significativo. As caninagens foram demonizadas pelos colonizadores desde seu primeiro contato com o Novo Mundo. Por conta disso, parte significativa dos esforços dos colonizadores, especialmente dos missionários, dirigiu-se à extinção das práticas etílicas dos índios "vistas como uma ameaça à colonização de seus corpos e mentes" (Fernandes 2005:54).

Segundo Carneiro (2002:199-0), em diferentes contextos culturais, a característica essencial do transe "é uma saída de si próprio, a perda de um autodomínio". Mas essa perda, explica, era controlada por meio de uma série de técnicas de ritualização, a que denomina de "domínio da perda do autodomínio". Para o autor, "é exatamente tal arsenal de técnicas de transe psicoquímico controlado que foi combatido mais fortemente pela evangelização moderna". Esta era, portanto, a razão pela qual a sociedade ocidental moderna "expurgasse com tamanha ojeriza as plantas alucinógenas da América e de outras regiões". Para o autor:

A recusa aos alucinógenos era, portanto, muito superior à das bebidas alcoólicas, e suas consequências são ainda hoje presentes na cultura ocidental, o que explica a permanência de um medo desproporcional dos alucinógenos ao mesmo tempo em que a embriaguez alcoólica não provoca nenhum temor excepcional. O álcool é um vício conde- 
nável, mas os alucinógenos são a loucura voluntária inaceitável (Carneiro 2002:200).

Contudo, a despeito de todas as perseguições sofridas, o saber herbóreo indígena penetrou nas mais distantes culturas, numa clara alusão ao que o historiador Carlo Ginzburg (1998) denomina de circularidade cultural. Ginzburg concebe a cultura como sendo produzida numa relação de circularidade entre as diferentes classes sociais. Nesse sentido, não há um locus privilegiado de produção da cultura, porquanto esta é resultado de modos históricos mediante os quais as desiguais classes sociais entram em relação dando origem a um amálgama cultural do qual se nutrem tanto dominantes quanto dominados.

Exemplo significativo de circularidade das práticas de consumo dos alucinógenos entre vários setores da sociedade colonial, pode-se conferir a partir do estudo de Gruzinski (2003) em sua análise acerca da complexidade dos processos de aculturação ocorridos no México espanhol. Para ele

seduzidos pela técnica divinatória, negros, mulatos, mestiços e espanhóis humildes - a 'gente de servicio', 'gente vil' - começaram por contratar os serviços de um curandeiro, depois passaram a obter as plantas sozinhos, aprenderam a consumi-las e, principalmente, a ver o que viam os índios (Gruzinski 2003:318).

Interpretadas como táticas de resistência, a circulação dessas práticas configurava-se como "dupla revanche indígena contra a Igreja”, posto que "ganhava adeptos e aparentemente fazia com que compartilhassem sua percepção do real e do numinoso" (Gruzinski 2003:318). Entretanto, é importante destacar que a perseguição à famacopéia indígena e aos seus usos, se insere dentro de um quadro complexo que envolve distintos significados, os quais só de longe são aqui pontuados.

Do ponto de vista político e econômico está o fato de que foi a existência de especiarias, chamadas drogas, que impulsionou o processo de consolidação do comércio possibilitado pela empresa de navegação marítima. Como afirmou Henrique Carneiro (2005b:12): "Foram as plantas exóticas, as especiarias tão prezadas, o estímulo para os périplos da navegação. A existência de diferentes drogas nas diversas partes da Terra foi a razão apresentada pelos homens para impulsionar o nascimento do comércio". Tais especiarias - entre as quais despontavam a "copaíba, quina, ipecacuanha, cabreúva, pedras bezoares de antas e de porcos-espinho, cacau, tabaco" e, sobretudo, o pau-brasil e o açúcar, consideradas, no Brasil, "as duas drogas mais importantes dos dois primeiros séculos da colônia", eram um dos alvos que constituía a missão catequética na Amazônia (Carneiro 2005b:13).

Nos dias de hoje, toda uma rede de vigilância existe do ponto de vista jurídico e social, tanto por parte das autoridades que regulam o uso das substâncias psicoativas, quanto por parte da sociedade que, em geral, tende a ver essas práticas como um problema social a ser combatido. 
Especificamente, no que se refere a ayahuasca, de acordo com McKenna (2002:174) as origens desse uso na bacia amazônica "estão perdidas por entre as névoas da pré-história", remontando à centenas ou milhares de anos. Desse modo, não é possível afirmar, com precisão, onde teria ocorrido o início dessa prática, posto que se trata de culturas que não deixaram registros escritos. Em suas investigações botânicas, McKenna (2002:175) afirma que:

Não existe nada sob a forma de material iconográfico, nem mesmo remanescentes botânicos que tenham sido preservados, que possa estabelecer o uso pré-histórico da ayahuasca; é provável que as culturas pré-colombianas, sofisticadas na utilização de grande variedade de plantas psicotrópicas, tenham tido uma relação familiar com a ayahuasca e seu preparo.

Para o autor, a "falta de datas nesta matéria é frustrante". Contudo, sabe-se que a utilização da ayahuasca disseminou-se por inúmeras tribos indígenas da bacia amazônica, e que antes de ter chamado a atenção dos etnógrafos ocidentais, na metade do século XIX, "o conhecimento das técnicas de preparação da ayahuasca, e também das plantas que lhe são apropriadas, já estava difundido na Amazônia" (Mckenna 2002:175).

Luna acredita que a ayahuasca é apenas uma beberagem psicoativa, em meio ao complexo uso dessas substâncias entre uma parte considerável da população pré-colombiana. Nesse complexo se inclui:
O peyote centro-americano, agora espalhado por toda a América do Norte nos rituais da Native American Church, numerosas espécies de fungos psilocibínicos usados por povos centro-americanos, o tabaco e a coca, as Brugmansias [...] sul-americanas, o cacto San Pedro [...] do Peru e Equador, os rapés, confeccionados a partir de duas espécies de Anadenantheras em áreas enormes da América do Sul [...], a resina da espécie de Virola, em regiões amazônicas (Luna 2005:334).

Mas, se por um lado a pré-história da ayahuasca permanece um mistério, sua história moderna é conhecida. Sua origem, afirma Mckenna (2002:176), remonta a 1851, quando o botânico inglês Richard Spruce "deparou-se com a utilização de uma beberagem intoxicante entre os índios da tribo Tucano do rio Uaupés, no Brasil". Spruce coletou espécimes do cipó, de que é feita a beberagem, o qual serviu de base para sua classificação, inicialmente como Banisteria caapi e, posteriormente, reclassificada em 1931, pelo toxicólogo Morton, como Banisteriopsis caapi. As descobertas de Spruce, contudo, só vieram a ser conhecidas em 1873, em uma narrativa popular que mencionava suas explorações na Amazônia. Segundo Mckenna (2002:176):

A exposição completa só pôde aparecer em 1908, quando Spruce publicou seu relato na antologia de A. R. Wallace, Notes of a Botanist on the Amazon and Andes (Spruce 1908). O crédito pelos primeiros estudos sobre o uso da ayahuasca pertence ao geógrafo equatoriano Manuel Villavicencio que, em 1858, escreveu a respeito de sua utilização 
na feitiçaria e na divinação do alto do rio Napo (Villavicencio 1858). Apesar de Villavicencio não ter fornecido detalhes botânicos sobre a planta aí empregada, o relato de sua auto-intoxicação não deixou dúvida em Spruce de que ambos escreviam sobre a mesma coisa.

Assim, embora documentada com precisão "há cerca de duzentos anos, seu uso é provavelmente milenar" (Luna 2005:334), não há dúvida de que o consumo da ayahuasca, originariamente, se situa na Bacia do Alto Amazonas. A história da Amazônia registra que, a partir do século XVII, missionários e colonos impuseram o catolicismo às sociedades indígenas locais, predominando, nessa região, as instituições católicas. Entretanto, desde o século XVI, a utilização indígena de sua farmacopéia constituída por poderosas plantas, desencadeou nos colonizadores uma reação preconceituosa e bastante severa. Citando o estudo de Taussig sobre o xamanismo, Mckenna (2002:199), afirma que “os espanhóis e os portugueses, justamente aqueles que ocuparam grande parte das florestas amazônicas", depois de constatarem a centralidade do uso dos psicoativos na indução dos estados de êxtase, "não só perseguiram brutalmente as culturas nativas como também as exploraram".

Entretanto, embora a população indígena seja, atualmente, minoritária na região, a atividade xamânica continua até hoje por meio das atividades de curandeiros e mestiços bem como das religiões ayahuasqueiras. A despeito da imposição religiosa do catolicismo, subsistiram, "as crenças mais diretamente ligadas ao meio ambiente, que não tinham substituto ou equivalente no cristianismo" (Macrae 1992:60). Entre essas crenças está o xamanismo, cuja figura central é o xamã, encarregado de "estabelecer contato com o mundo sobrenatural, buscando influir na cura de doenças, servir de oráculo, proporcionar bons resultados em caçadas, evitar catástrofes naturais e organizar cerimônias religiosas" (Macrae 1992:28).

Para o autor, o xamanismo é a instituição religiosa mais importante que o caboclo da Amazônia preservou da cultura indígena. Embora tenha adotado "orações cristãs, colocado santos católicos na categoria de espíritos familiares, ao lado das entidades sobrenaturais da água ou da mata, o xamanismo ainda é um dos legados culturais indígenas menos modificados" (Macrae 1992:127).

Os poderes do xamã são adquiridos seja por "vocação pessoal, pela vontade de agentes sobrenaturais ou, às vezes, por herança" (Macrae 1992:28). São também conhecidos como curandeiros, ${ }^{10}$ mestiços ${ }^{11}$ ou vegetalistas e descendem do contato entre indígenas, "portugueses, espanhóis e negros" que, apesar da colonização ibérica, da atividade catequética e da economia da borracha na Amazônia, mantém elementos dos antigos conhecimentos indígenas acerca das plantas, seu uso e relação com o mundo espiritual (Macrae 1992:29).

A amplitude dos conhecimentos dos xamãs é significativa. Eles "eram fre- 
quentemente grandes contadores de histórias, dotados de talento artístico e de memória extraordinária" (Macrae 1992:31). São também "grandes conhecedores da floresta e das propriedades das plantas, que usam com frequência, especialmente para atividades de cura" (Macrae 1992:28). ${ }^{12}$ Provém, portanto, das plantas a mutiplicidade de saberes necessários à vida prática:

A utilização correta das plantas permite então o aprendizado do conhecimento que será necessário para suas futuras práticas xamânicas. Sua mente está "aberta" para que ele possa então explorar adequadamente a fauna, a flora e a sua localização geográfica, assim como lembrar-se de tudo isso mais tarde. As plantas comunicam-se com ele através de visões e sonhos e, além da "sabedoria", transmitem-lhe também "força", ou seja, qualidades físicas como resistência a ventos, chuvas e inundações (Macrae 1992:32).

Entre os Machiguenga, o xamã ou curandeiro é chamado de seripigari que significa "intoxicado por tabaco". Um seripigari poderoso, na perspectiva desses grupos, é aquele que: a) consegue curar doenças consideradas incuráveis pela medicina ocidental; b) sabe utilizar canções a fim de "contactar espíritos poderosos ou chamar de volta a alma de uma pessoa doente"; d) sabe usar seu corpo para "localizar e remover objetos intrusos" que entram no corpo através da bruxaria causando doenças como, por exemplo, espinhos, pedras, ervas... (Shepard Jr. 2005:193). Entretanto, o xamã não é apenas um ótimo curandeiro:
Ele é o embaixador da humanidade no cosmos, que negocia a seu favor com as forças da natureza e com os espíritos poderosos que controlam os assuntos de vida e morte na terra. Como parte de sua atuação ecológica e cosmológica, o seripigari chama os animais de caça de seus esconderijos quando falta caça, traz novas variedades de cultivo e de plantas medicinais do mundo espiritual e consegue controlar o tempo e outros elementos da natureza (Shepard Jr. 2005:193).

A habilidade de um xamã depende não apenas do contato com o mundo espiritual, mas, especialmente, da realização de "um treinamento adequado". Ainda que afirmem que seus saberes se originam diretamente das plantas professoras, "a maioria deles recebeu tal conhecimento durante um treinamento formal com um outro xamã, denominado dieta" (Bianchi 2005:325). Luna (2002:184), afirma que em especial, o xamã deve "evitar ingerir sal, açúcar, especiarias e gorduras". Além disso, deve evitar expor-se em demasia ao calor do sol ou ao fogo e ainda manter-se isolado, "guardando suas energias sexuais" (Bianchi 2005:184). Um dos objetivos da dieta é o de "aprimorar o corpo do xamã, de modo que seus odores tornem-se agradáveis aos espíritos das plantas" (Bianchi 2005:325).

A dieta, portanto, é "um conceito muito amplo e personalizado na Amazônia peruana" e transcende à dimensão estritamente alimentar uma vez que "está relacionada com a ideia de privação material, psicológica e social, com o objetivo de direcionar toda a atenção da pessoa para a dimensão espiritual”. 
Cabe ressaltar, nesse contexto, o ângulo psicológico que a experiência da ayahuasca necessariariamente impacta.

\subsection{A ayahuasca e os territórios da mente}

Um campo privilegiado de estudos sobre a ayahuasca é aquele relacionado à psicologia cognitiva. A despeito da contribuição analítica das ciências naturais (a exemplo da botânica e etnobotânica, farmacologia, bioquímica e fisiologia do cérebro) e das ciências sociais, em especial, a antropologia, com inúmeras pesquisas sobre esta beberagem, o psicólogo Benny Shanon (2002:633) afirma, que "o enigma real associado com esta bebida não pertence nem ao cérebro e nem à cultura, mas sim à mente humana".

Segundo Shanon (2002:634), a ayahuasca "é um instrumento para descobrir novos territórios inexplorados e desconhecidos da mente humana" e, nesse sentido, a psicologia cognitiva pode "oferecer um mapa sistemático do fenômeno especial apresentado pela ayahuasca" e conceitualizá-lo relativamente ao conhecimento acerca do funcionamento da mente, "seja a mente de um índio ou de um cowboy".

Ao fazer uma caracterização fenomenológica da experiência da ayahuasca, $\mathrm{o}$ autor esboça uma tipologia das questões que esta experiência levanta no que concerne ao domínio da psicologia cognitiva, tipologia esta apresentada sob a nomeclatura agrupamento. Afir$\mathrm{ma} \mathrm{o}$ autor, que $o$ primeiro agrupamento envolve questões fenomenológicas de primeira ordem: Trata-se de indagar sobre "o que está sendo experimentado?". Esta pergunta pressupõe uma primeira subclassificação a que denomina tipo de domínio. Os diferentes domínios correspondem "as diferentes regiões da geografia da mente que são reveladas pela inebriação da ayahuasca" (Shanon 2002:635).

Em primeiro lugar, o autor chama atenção para a atmosfera geral causada pela inebriação e os sentimentos gerais - físicos e corporais que lhe são associados. Os que mais se destacam são os "efeitos sensório-motores" que compreendem todas as modalidades: "visual, a auditiva, a olfativo-gustativa e a tátil". Salienta-se também "os efeitos sinestésicos" em que "percepções de modalidades mistas são encontradas" (Shanon 2002:636). Não menos importantes são os "efeitos ideacionais" em que

sob a influência da ayahuasca as pessoas sentem que suas mentes funcionam mais rápido e melhor do que normalmente e elas referem-se a muitas novas ideias, intravisões e reflexões que lhe ocorrem. [...] Intravisões relacionando-se à personalidade e vida de alguém, intravisões intelectuais e reflexões pertencentes aos domínios específicos de interesse de alguém, e ideias filosóficas e metafísicas de significância geral (Shanon 2002:636).

Além desses efeitos, o autor refere-se aqueles relacionados às "mudanças na estrutura da consciência e de si (self)" a que estão associadas às experiências de "metamorfose nas quais alguém sente que sua identidade pessoal se transforma (por exemplo, para a identidade de outra pessoa ou de um animal)". Há 
efeitos que podem ser publicamente observados como, por exemplo, pessoas que exibem uma performance musical maior do que exibiriam normalmente. E finalmente, há as experiências espirituais e misticas as quais têm um impacto profundo e quase sempre resultam em "transformações pessoais significativas” (Shanon 2002:636).

A segunda sub-classificação está relacionada ao conteúdo da experiência em que se indaga sobre "que tipo de coisa alguém faz e vê nas visões da ayahuasca?" (Shanon 2002:637).

Se alguém vê, digamos, pessoas, animais ou paisagens, pode-se também apontar se as imagens que as pessoas têm nas visões são imóveis ou móveis, de alta definição ou difusas, constituindo-se de tomadas simples ou definindo séries inteiras, como um filme (Shanon 2002:637).

O segundo agrupamento principal refere-se às questões de segunda ordem. Entre estas questões estão: "há uma ordem no que é experienciado? Há regularidade na progressão das visões e outras experiências induzidas pela ayahuasca? Podem ser definidos estágios distintos?" (Shanon 2002:637-8). O terceiro agrupamento refere-se às questões relativas à dinâmica isto é a investigação dos "padrões estruturais pelos quais uma imagem leva a outra" (Shanon 2002:638). O quarto agrupamento é o das questões contextuais que investiga "como as várias facetas da intoxicação são afetadas pelo contexto no qual a pessoa sob efeito da ayahuasca é situada" (Shanon 2002:638).

Especulando acerca das possíveis contribuições da ayahuasca para o estudo da mente, o autor afirma que não são suficientes as suposições baseadas no que chama de "estados padrão de consciência", sobretudo a vigília e o sonho, sendo também necessário abordar os fatos da mente "não padrão", fatos estes que a ayahuasca, e outros agentes psicoativos, podem revelar. Conclui afirmando a "máxima significância psicológica cognitiva” desta beberagem (Shanon 2002:640).

$\mathrm{Na}$ ampla investigação que desenvolveu, Benny Shanon tomou como fontes de pesquisa suas experiências pessoais de consumo da ayahuasca, a análise da literatura especializada, restringindo, contudo, o artigo em análise, às pinturas do ex-curandeiro peruano Pablo Amaringo, produzidas sob a inspiração dessa bebida. ${ }^{13}$ Considerou, ainda, entrevistas diversas realizadas com diferenciados usuários da ayahuasca. ${ }^{14} \mathrm{~A}$ partir dos dados obtidos, o autor desenvolveu um sistema de categorização em que agrupa itens relativos ao conteúdo dessas experiências, com destaque ao que denomina de "comunhões suprasensíveis na experiência da ayahuasca" de diferentes sujeitos (Shanon 2002:641). Os itens relativos a esse conteúdo, retirado das três fontes mencionadas, foram organizadas pelo autor em três quadros e agrupadas nas seguintes categorias:

Conteúdos pertencentes à história de vida de alguém, seres humanos, animais naturais, animais não naturais, seres que não são nem humanos nem animais (como ninfas, gnomos, criatura meio humana, meio animal), plantas e seres botânicos, lugares geográficos, cidades não geográficas (esta categoria 
inclui cidades antigas, futurísticas e encantadas) paisagens naturais, construções arquitetônicas, objetos e artefatos, veículos de transporte, símbolos e scripts, cenas divinas e celestiais, seres divinos e semi-divinos (como anjos, Jesus, Cristo, Buda), itens e cenas pertencentes a civilizações antigas, figuras históricas e cenas, figuras mitológicas e cenas, episódios pertencentes à morte e visões na quais a luz era central. Há também itens específicos que não se enquadram em qualquer categoria (Shanon 2002:645).

Dentre as conclusões a que chega, destaca que "os quadros revelam um núcleo comum bastante substancioso", tendo sido coletados a partir de diferentes pessoas, em ambientes e condições diferenciadas, iindício que "a experiência da ayahuasca revela alguns universais da mente inexplorados" (Shanon 2002:649).

Shanon (2002:650) destaca que os itens relativos à natureza estão em lugar privilegiado, particularmente, a visão de felinos, serpentes e pássaros. E isto, afirma, "é verdade para um 'garoto da cidade' como eu, que vem de uma cultura diferente da Amazônia”. Contraditoriamente, alguns dos ítens mais comuns que se destacam "pertencem à cultura", tais como palácios e complexos arquitetônicos, e tais itens, complementa, "foram também relatados pelos indígenas para mim”. Assim, conclui:

Não posso afiançar que estas pessoas jamais viram grandes construções arquitetônicas ou suas pinturas. É também bastante improvável que eles tivessem, alguma vez, visto o tipo de edifícios maravilhosa- mente elaborados que ricamente ornamentam os trabalhos de arte que a ayahuasca apresentou para eles nas visões que gerou em suas mentes (Shanon 2002:650).

Outra conclusão de Benny Shanon (2002:652) refere-se ao fato de que as comunhões interpessoais possibilitadas pela ayahuasca não se restringem aos conteúdos das visões dos diferentes sujeitos, sendo também encontradas em outros domínios dessa experiência como, por exemplo, nas "ideias filosóficas que a bebida gera na mente das pessoas". Segundo o autor:

A maioria delas pode ser caracterizada como pertencentes ao idealismo monístico e muitas são remanescentes de ideias encontradas em Platão, Plotinus, Spinoza e Hegel. Eminentemente, tais ideias são expressas por pessoas sem familiaridade nesses trabalhos filosóficos (Shanon 2002:652).

Esta conclusão me faz pensar se não estaríamos assistindo, a partir da experiência da ayahuasca, a um movimento contrário ao estabelecido pela ciência moderna ocidental, de retorno das preocupações metafísicas, em meio à rotina agitada da vida moderna. Consoante uma previsão de Santos (1997:38): "os conceitos de 'mente imanente', 'mente mais ampla' e 'mente colectiva' de Bateson e outros, constituem notícias dispersas de que o outro foragido da ciência moderna, Deus, pode estar em vias de regressar". A experiência da ayahuasca estaria a recolocar este foragido no centro da vida?

Outro aspecto da pesquisa de Shanon que vale a pena destacar refere-se 
ao que ele denomina de parâmetros da consciência. Admitindo a complexidade e multiplicidade de uma definição do que seja consciência, o autor focaliza em seu texto apenas um aspecto da questão que considera estrutural. Para ele, estruturalmente,

A consciência consiste num conjunto de parâmetros que definem valores especificando a maneira como seres humanos experienciam o mundo - tanto físico quanto mental. Se estes valores mudassem, a fenomenologia da experiência seria alterada. A apreciação dos parâmetros e a determinação de seus valores não é sempre fácil. Algumas das características da consciência são tão engrenadas em nosso modo de ser que elas são tomadas como dadas e nós somos, usualmente cegos a elas. A situação é completamente análoga àquela encontrada no caso dos óculos. Se alguém continuamente usasse óculos que colorissem o mundo ou transformassem o ângulo de visão, esse alguém tomaria as transformações mencionadas como dadas e não estaria consciente da existência dos óculos (Shanon 2002:653).

$\mathrm{Na}$ sua análise, os estados de consciência alterada têm a grande contribuição de testemunhar "os diferentes valores possíveis daqueles parâmetros dos quais normalmente não somos conhecedores". Dentre estes parâmetros, em primeiro lugar, o autor destaca o que denomina de agência - este "talvez o traço estrutural mais básico da consciência humana" considerando a análise clássica da fenomenologia da consciência definida por Willian James (Shanon 2002:653).
Nesse sentido, "experimentalmente, todo material mental do qual qualquer indivíduo está consciente pertence a um, e apenas um, agente cognitivo, nomeadamente aquele único indivíduo". Assim, "os pensamentos que eu tenho são meus pensamentos, as memórias que eu tenho são minhas memórias, as percepções que eu tenho são minhas, os sonhos que eu sonho são meus sonhos" (Shanon 2002:653). Entretanto, afirma o autor, os padrões alterados da consciência, tais como os possibilitados pelo consumo de ayahuasca, podem modificar tudo isso, pois

Há instâncias nas quais pensa-se que os pensamentos que ocorrem a alguém não são os seus próprios, casos nos quais as mentatio de alguém parecem governadas e dirigidas por outros agentes e, ao contrário, casos nos quais alguém pensa que é secreto para o material mental de outra pessoa (Shanon 2002:653).

O usual, diz o autor, é que as pessoas pensem que seus pensamentos são de si próprias. Contudo, depois de ingerir a ayahuasca, "alguém pode pensar que não é este o caso" (Shanon 2002:653). Mas então, indago: a experiência da ayahuasca subverte a visão científica da consciência que, normalmente, tomamos como dada? De que forma os saberes tidos como tradicionais da ayahuasca podem implicar na analítica das ciências da mente?

Em segundo lugar, o autor considera os parâmetros estruturais relativos ao self e sua diferenciação do não-self. Afirma que um aspecto "chave" para a consciência é que "ela dispõe de distin- 
ções entre eu e não-eu (self e não-self) e entre o mundo interno, psicológico e o externo". Entretanto, todas essas diferenciações podem tornar-se "confusas, difusas ou mesmo, localmente abolidas", sob o efeito da ayahuasca. O que é mais comum "é o senso de identificação profunda, que pode ser visto como uma relação mística entre o agente cognitivo e o mundo". Assim, sob esse estado "a distinção fundamental entre o interno e o externo parece não mais aplicável" (Shanon 2002:654). Pergunto então, se não estamos diante de uma experiência que, ao contrário de criar mais abismos, contribui para dissolver fronteiras profundas e inimagináveis, ainda que momentaneamente?

Outra modificação possibilitada pela ayahuasca refere-se à questão da identidade pessoal. Para Shanon (2002:654), normalmente, cada ser humano tem uma identidade bem definida, salvo nos "casos de psicose pessoal em que a noção de identidade pessoal pode ser perturbada". Ora, um fenômeno que a experiência da ayahuasca induz é a chamada "metamorfose", situação em que "as pessoas podem sentir que sua identidade pessoal muda", como atesta o estudo e a vivência pessoal do autor:

Nas entrevistas que conduzi com outros usuários não indígenas da bebida, a transformação para pássaro é a metamorfose animal mais comum; eu também experimentei este tipo de metamorfose. Bastante comum é a transformação em outro ser humano. $\mathrm{O}$ tipo menos frequente de metamorfose é para entidades não animadas. $\mathrm{O}$ relato deste gênero mais impressionante que recebi de um informante foi o de uma pessoa transformando-se em uma gota d'água, em um pedaço de terra e em um ponteiro de um relógio (Shanon 2002:655).

Pergunto, então: a experiência da metamorfose possibilitada pela ayahuasca estaria a anular, ainda que momentaneamente, a clássica dicotomia entre humano e não humanos definida como verdade ontológica pela ciência moderna?

Outro parâmetro da consciência focalizado por Benny Shanon (2002:655) tem a ver com a questão do tempo que, para Emmanuel Kant, "é a condição básica para nossa vida mental”. Entretanto, a temporalidade padrão da cognição humana não se aplica a partir da experiência da ayahuasca posto que "são encontrados vários padrões surpreendentes da temporalidade psicológica". É assim que,

Sempre alguém sente que a velocidade da passagem do tempo muda - o tempo parece passar mais depressa ou mais devagar do que o relógio indica. Mais notável, eu acho, são aqueles casos nos quais pensa-se que o tempo pára. Com isso, pensa-se que se entrou num outro domínio de existência (Shanon 2002:655).

Os vários padrões de temporalidade, induzidos pela ayahuasca, foram bastante perturbadores para o próprio autor, pois conforme sua confissão, antes de conhecer esta bebida, argumentava em seus estudos da mente que "a cognição humana é intrinsecamente temporal". Contudo, sob o efeito da ayahuasca afirma ter encontrado "uma experiência que afronta o tempo" 
(Shanon 2002:655). Atualmente, diz o autor,

Defendo a ideia de que a cognição humana é normalmente, de fato, enraizada na temporalidade. A mente humana exibe, entretanto, uma façanha das mais admiráveis, pela qual, em situações especiais, pode entrar em "outro funcionamento", por assim dizer, e operar em um modo atemporal (Shanon 2002:655).

Quando se toma ayahuasca, o tempo não é mais o tempo cronológico do relógio, mas o tempo do cipó. A ayahuasca, ao subverter as clássicas noções de tempo, configura-se como uma experiência que o afronta, e com isso, desafia a visão dominante ao instituir outros modos de vivenciar a temporalidade.

\section{CONSIDERAÇÕES FINAIS}

A discussão sobre as plantas professoras está imbricada a uma variedade de campos do saber, a exemplo da botânica, farmacologia, psicologia, história, entre outros, constituindo as diversas formas de uso dessas plantas um campo original de conhecimento.

Embora conhecidas em diversas partes do mundo, é necessário ressaltar o vasto saber herbóreo das populações indígenas existentes nas Américas, principalmente no que tange aquela que é considerada a planta mestra por excelência, a ayahuasca. Suas possibilidades cognitivas são destacadas em vários estudos considerando as diversas aprendizagens que seu consumo mobiliza no sujeito: conhecimentos sobre a fauna e a flora, ideias filosóficas de natureza metafísica, habilidades musicais, experiências de contato com a divindade e os diversos casos de cura em que é empregada. Destaca-se suas potencialidades enquanto mediadora de conhecimentos do mundo natural, em especial do reino vegetal. Seu maior impacto, entretanto, é na psique uma vez que a ayahuasca é considerada um poderoso instrumento para descobrir territórios desconhecidos da mente humana.

A despeito das várias dimensões em que o consumo das plantas professoras está enredado, chamo atenção para as suas dimensões sagradas, ambientais, medicinais e, fundamentalmente, pedagógicas motivo pelo qual exercem grande influência nos processos de sobrevivência e perpetuação dos saberes de diversos grupos que a utilizam. Seu consumo milenar em diferentes espaços e culturas constitui, assim, um instigante objeto para a historiografia, ainda bastante lacunar no que se refere a uma história cultural das plantas, em particular as plantas professoras.

Ocontatodos europeus com a complexa farmacopéia indígena constituída por poderosas plantas alucinógenas, cuja embriaguez provocava diversas transgressões morais, foi motivo de perplexidade e choque cultural. Em vista disso, essas plantas foram alvo de intensa campanha da Igreja contra o amplo saber herbóreo indígena e seu complexo arsenal de técnicas do êxtase.

Todavia, a despeito de todas as perseguições sofridas, o saber herbóreo indígena penetrou nas mais distantes culturas, numa clara alusão ao que o historiador Carlo Ginzburg (1998) 
denomina de circularidade cultural. A atividade xamânica continua até hoje por meio das atividades de curandeiros e mestiços, bem como das religiões ayahuasqueiras que fazem uso desta beberagem feitas de plantas da Amazônia com finalidades diversas, em especial para a cura de doenças e o autoconhecimento.

\section{NOTAS}

${ }^{1}$ Com modificações, este texto foi publicado originalmente no livro de Albuquerque, M.B.B. 2011. Epistemologia e Saberes da Ayahuasca. Belém: EDUEPA.

${ }^{2} \mathrm{Dr}^{\mathrm{a}}$ em Educação pela Pontifícia Universidade Católica de São Paulo (PUC/SP); Professora do Programa de Pós-Graduação em Educação da Universidade do Estado do Pará (UEPA); mbetaniaalbuquerque@,uol.com.br

${ }^{3}$ Este é o modo "clássico" de se preparar ayahuasca. Existem, contudo, outras espécies que podem ser acrescentadas, além de outra forma de preparo que não prevê o cozimento das plantas (Luna 2005); (Mckenna 2002).

${ }^{4}$ Para uma história etnofarmacológica da ayahuasca, vide o texto de Mckenna (2002).

${ }^{5}$ Existe ainda outro alcalóide: a harmalina, mas este é em "quantidades insignificantes do ponto de vista da ação da ayahuasca" (Luna 2005:335).

${ }^{6}$ A despeito de suas especificidades, tais religiões possuem algumas características comuns, são elas: a sua natureza híbrida formada a partir de diversas tradições religiosas; terem sido criadas por homens provenientes do nordeste brasileiro; por trabalhadores dos seringais da Amazônia e, fundamentalmente, por consagrarem o uso ritualístico da ayahuasca.
${ }^{7} \mathrm{O}$ termo vegetalista é sinônimo de curandeiro e alude "à origem de seus conhecimentos, atribuída aos espíritos de certas plantas, que seriam os verdadeiros professores dos xamãs" (Macrae 1992:30).

${ }^{8}$ Segundo Fontes (2008) a mescalina foi sintetizada em laboratório em 1919 e suscitou o interesse imediato da psiquiatria devido aos efeitos de insanidade que possibilitavam compreender e tratar patologias mentais.

${ }^{9}$ LSD (dietilamida do ácido lisérgico), segundo Fontes (2008:13), é um “alucinógeno sintético lançado em 1947 pelo laboratório farmacêutico suíço Sandoz". Diz o autor que, "aliando potência e não toxicidade, de fato o LSD prometia ser uma ferramenta ímpar para aceder às dimensões ocultas da mente".

${ }^{10}$ Antônio Bianchi (2005:323), explica que a transformação das culturas indígenas de nômades para sedentárias é caracterizada por uma menor dependência em relação à caça como forma de sobrevivência. Este fato fez com que preocupações ecológicas fossem substituída pelas preocupações com a saúde alterando a função maior do xamã como intermediário entre o mundo dos homens e o mundo dos espíritos. O xamã torna-se, então, um "curandero (curandeiro), aquele que cura".

${ }^{11}$ A palavra mestizo (mestiço) caracteriza as "populações não nativas que colonizaram a Amazônia peruana na época da borracha" (Bianchi 2005:320).

12 As atividades do xamã, contudo, possuem segundo MacRae (1992:28), uma ambivalência: atribuem-se a ele "tanto o poder de curar quanto o de fazer o mal".

${ }^{13}$ Luis Eduardo Luna (2002:191) descreve o pintor Pablo Amaringo como "uma pessoa de grandes conhecimentos sobre vegetalismo ribeirinho, $[. .$.$] , conhecia intimamente$ a ayahuasca por ter sido aparentemente 
afamado curandeiro durante uns sete anos, e demonstrava ter um conhecimento íntimo do meio ambiente selvático".

${ }^{14}$ A ampla pesquisa realizada pelo autor inclui como informantes "indígenas e não indígenas, pajés e mestres das cerimônias da ayahuasca, pessoas com longa experiência com a bebida e pessoas que haviam experimentado pela primeira vez". As entrevistas ocorreram em locais diferenciados: Brasil, Peru e com pessoas fora da América Latina. Contudo, no artigo em questão, o autor focaliza apenas um grupo de usuários residentes no Brasil, a maioria na cidade do Rio de Janeiro (Shanon 2002:643).

\section{REFERÊNCIAS}

Bianchi A. 2005. Ayahuasca e xamanismo indígena na selva peruana: o lento caminho da conquista, In O uso ritual das plantas de poder. B. C. Labate e S. L. Goulart (orgs.), pp. 319-331. Campinas: Mercado de Letras.

Burke, P. 2005. O que é história cultural. Rio de Janeiro: Jorge Zahar Editor.

Carneiro H. 2002. Amores e sonhos da flora: afrodisíacos e alucinógenos na botânica e na farmácia. São Paulo: Xamã.

.2005a. A odisséia psiconáutica: a história de um século e meio de pesquisas sobre plantas e substâncias psicoativas, In O uso ritual das plantas de poder. B. C. Labate e S. L. Goulart (orgs.), pp 57-82. Campinas: Mercado de Letras.

.2005b. Transformações do significado da palavra "droga": das especiarias coloniais ao proibicionismo contemporâneo, In Álcool e drogas na história do Brasil. R. P. Venâncio e H. Carneiro, pp. 11-27. São Paulo: ALAMEDA, Belo Horizonte: Editora da PUCMinas.

Druot, P. 1999. Luz no horizonte in Revista Isto É 1571. Disponível em: em <http://www.terra.com.br/istoe/vermelha/157102.htm>. Acesso em 20 jan. 2006.

Escohotado A. 2004. História elementar das drogas. Lisboa: Antígona.

Fernandes J. A. 2005. Guerreiros em transe in Revista de História da Biblioteca Nacional 4: 52-57.

Furst P. 1989. Cogumelos psicodélicos. São Paulo: Editora Nova Cultural. (Col. Tudo sobre drogas).

Ginzburg C. 1989. Sinais: Raízes de um paradigma indiciário, In Mitos, emblemas, sinais: morfologia e história. C. Ginzburg, pp. 143-179. Trad. de Frederico Carotti. São Paulo: Companhia das Letras.

1998. O queijo e os vermes: o cotidiano e as ideias de um moleiro perseguido pela Inquisição. São Paulo: Companhia das Letras.

Goulart, S. L. 2005. Contrastes e continuidades em uma tradição religiosa amazônica: os casos do Santo Daime, da Barquinha e UDV, In O uso ritual das plantas de poder. B. C. Labate e S. L. Goulart (orgs.), pp. 355 396. Campinas: Mercado de Letras.

Grob, C. 2002. A psicologia da ayahuasca, In Ayahuasca: alucinógenos, consciência e o espírito da natureza. R. Metzner, pp. 195 225. Rio de Janeiro: Griphus.

Gruzinski S. 2003. A colonização do imaginário: sociedades indígenas e ocidentalização no México espanhol, séculos XVI-XVIII. São Paulo: Companhia das Letras.

Labate, B. C. 2004. A reinvenção do uso da Ayabuasca nos centros urbanos. Campinas: Mercado de Letras; São Paulo: FAPESP.

Leary, T. 2001. Your Brain Is God. Califórnia: Editora Berkeley. (série Leary library). Disponível em: <http://www.scribd. com/doc/5708664/Timothy-Leary-Seu-Cerebro-e-Deus-Your-Brain-is-God-Portugues>. Acesso em 15 jun. 2009. 
Luna L. E. 2002. Xamanismo amazônico, ayahuasca, antropomorfismo e mundo natural, In O uso ritual da Ayabuasca. B. C. Labate e W. S. Araújo (orgs.), pp. 179-198. Campinas: Mercado das Letras; São Paulo: FAPESP.

2005. Narrativas da alteridade: a ayahuasca e o motivo de transformação em animal, In O uso ritual das plantas de poder. B. C. Labate e S. L. Goulart (orgs.), pp. 333354. Campinas: Mercado de Letras.

Macrae E. 1992. Guiado pela Lua: xamanismo e uso ritual da ayahuasca no culto do Santo Daime. São Paulo: Editora Brasiliense.

Mckenna D. J. 2002. Ayahuasca: uma história etnofarmacológica, In Ayahuasca: alucinógenos, consciência e o espírito da natureza. Ralfh Metzner (org.), pp. 172194. Trad. Marcia Frazão. Rio de Janeiro: Gryphus.

Metzner, R. (org.). 2002. Ayahuasca: alucinógenos, consciência e o espírito da natureza. Trad. Marcia Frazão. Rio de Janeiro: Gryphus.

Richardson, P. Mick. 1988. Flores Alucinógenas. São Paulo: Editora Nova Cultural. (Col. Tudo sobre drogas).

Samorini, G. 2005. Buiti: religião enteógena africana, In $O$ uso ritual das plantas de poder. B. C. Labate e S. L. Goulart (orgs.), pp. 301-317. Campinas: Mercado de Letras.

Shanon B. 2002. A ayahuasca e o estudo da mente. In O uso ritual da Ayahuasca. B. C. Labate e W. S. Araújo (orgs.), pp. 631-660. Campinas: Mercado das Letras; São Paulo: FAPESP.

Shepard Jr., G. 2005. Venenos divinos: plantas psiocativas dos machiguenga do Peru, In O uso ritual das plantas de poder. B. C. Labate e S. L. Goulart (orgs.), pp. 187-218. Campinas: Mercado de Letras, 2005.
Santos, B. de S. 1997. Um discurso sobre as ciências. 9 ed. Porto: Edições Afrontamento. Souza, L. de M. 1986. O diabo e a terra de Santa Cru₹: São Paulo: Companhia das Letras.

Vainfas, R. (org.). 2000. Dicionário do Brasil colonial: 1500-1808. Rio de Janeiro: Objetiva.

Recebido em 10/06/2017

Aprovado em 02/08/2017 